\title{
症例報告
}

エタネルセプト投与中に微小変化型ネフローゼ症候群を来たした関節リウマチの 1 症例

竹内孝男*1, 竹川麻衣*1, 伊藤能永*1

岸史*2, 宮本昌彦*2, 南方保*2

\section{Minimal change nephrotic syndrome developing in a rheumatoid arthritis patient under etanercept treatment}

\author{
Takao TAKEUCHI ${ }^{* 1}$, Mai TAKEGAWA ${ }^{* 1}$, Yoshinaga ITO*1, \\ Fumi KISHI ${ }^{* 2}$, Masahiko MIYAMOTO*2 and Tamotsu MINAKATA ${ }^{* 2}$ \\ ${ }^{*}$ Department of Clinical immunology and rheumatology, Osaka Red Cross Hospital \\ ${ }^{*}$ Department of nephrology, Osaka Red Cross Hospital
}

(Received March 6, 2008)

\begin{abstract}
summary
A 67-year-old female patient with rheumatoid arthritis (RA) developed minimal change nephrotic syndrome (MCNS) while under treatment with etanercept (ETN). Histopathological examination of renal biopsy specimens showed minimal-change nephropathy. Almost complete resolution of the MCNS was achieved by discontinuation of ETN and initiation of steroid therapy. There have been no reports from Japan of the occurrence of MCNS caused by ETN administration in RA patients, and only very few cases have been reported from around the world. Therefore, this case was considered to be very uncommon and worthy of reporting, and herein is a report of our patient.
\end{abstract}

Key words_-Adverse effect; Etanercept; Minimal change nephrotic syndrome; Rheumatoid arthritis; Nephrotic syndrome

抄録

67 歳, 女性. Rheumatoid arthritis（RA）患者の治療として, エタネルセプト（ETN）を投与中に, 微小変化型 ネフローゼ症候群（MCNS）を発症した。腎生検後，ETN を中止し，ステロイド剤の投与で，MCNS はほぼ完治 した．ETNの投与により，MCNS を来たした RA 症例は今迄に本邦では報告が無く，また海外の文献でも数例を 認めるに過ぎず，非常に稀であると考えられ，症例呈示と共に，その病態メカニズムに文献的考察を加えた.

はじめに

関節リウマチ（RA）の治療として生物学的製剤 が主流になりつつある1〜3)が，TNF 阻害薬の代表的 なレセプター製剤であるエタネルセプト（ETN） を投与中に微小変化型ネフローゼ症候群（MCNS） を来たした 1 症例を我々は経験した。腎生検の病理 組織学的所見で確定診断後, ETN を中止し，ステ ロイド剤により，MCNS はほぼ完治したＥTNNの 投与により，MCNS を来たした RA 症例は今迄に 本邦では報告がなく，海外の文献も少なく，本例は 稀有な例であり，ここに症例呈示し，その病態メカ

\footnotetext{
${ }^{*}{ }_{1}$ 大阪赤十字病院リウマチ・膠原病内科

*2大阪赤十字病院腎臓内科
}

ニズムに考察を加えた.

\section{症例}

67 歳, 女性.

主 訴: 下腿浮腫抢よび蛋白尿

既往歴 : 50 歳：気管支喘息. 肺結核の既往はな い.

家族歴 : 特記すべき事なし。

現病歴: 2005 年 2 月初めより多発性関節痛を来 たすようになり，近医を受診した。 RA（stage II, class 2) の診断にて 5 月より MTX $4 \mathrm{mg}$ /週の投与 を開始され，3 月半継続したが症状が改善せず， 中止となった. 8 月 31 日当院リウマチ・膠原病内 科を初診し, ETN の適応基準に合致し, 承諾が得 られたため，9月 16 日より ETN $25 \mathrm{mg} /$ 回，2 回/ 
週の皮下注射を開始した（開始時 DAS28 は ESR (4)

6.22, CRP (4) 4.97). 9 月下旬には DAS28 は ESR (4) 4.69, CRP (4) 3.37 と回復したが，この頃より労 作時呼吸困難，尿量減少などの症状が出現. 10 月 31 日外来受診時足背に浮腫を認め, 低アルブミン 血症（血清アルブミン $3.3 \mathrm{~g} / \mathrm{dl}$ ）もあった. 11 月 14 日アルブミン $2.9 \mathrm{~g} / \mathrm{dl}$ と更に低下し，蛋白尿も 認め，総コレステロール $339 \mathrm{mg} / \mathrm{dl}$ とネフローゼ症 候群（NS）の診断基準を満たし，ETN の有害事象 の可能性が考えられたため同日より中止. 精查加療 目的にて 12 月 2 日入院となった。この間の血清ア ルブミン, 尿蛋白, 尿潜血の推移を表 1 に示す.
入院後の経過 : 入院時の主な検査結果は表 2 に示 した.

12 月 5 日に腎生検を施行. HE 染色で糸球体は 正常で，尿細管間質性線維化も認められなかった (図 1). Perodic acid silver methenamine (PASM) 染色では double contour や spike はなく（図2）, 蛍光抗体法では， $\kappa, \lambda$ を含め全て染色されず，電 顕では広範な足突起の閉鎖（effacement）と上皮細 胞に打ける微絨毛の存在が認められた（図 3). 病 理学的組織所見としてはMCNS であった。

ETN を中止したところ蛋白尿は減少傾向となっ たが，入院時に血清アルブミンが $2.3 \mathrm{~g} / \mathrm{dl}$ と低值で

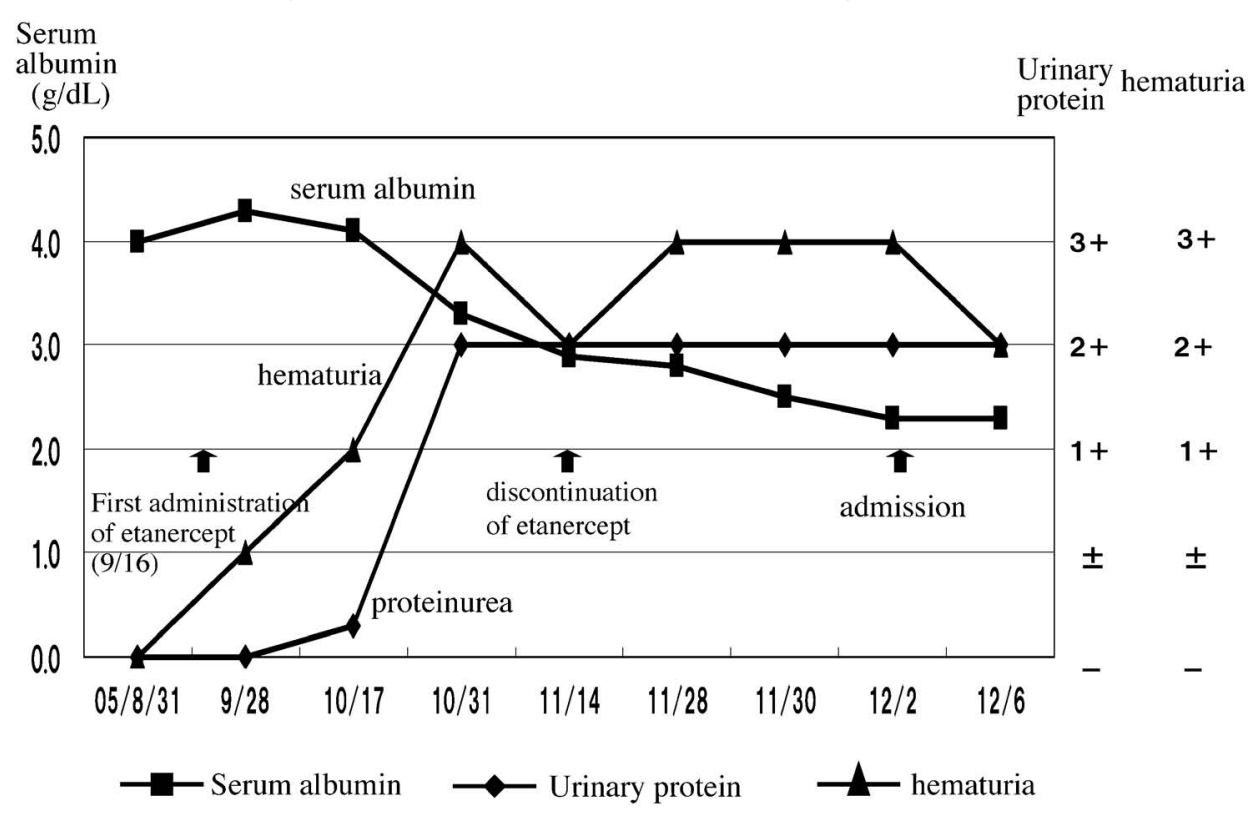

表 2 入院時検査成績

\begin{tabular}{|c|c|c|c|}
\hline \multicolumn{4}{|c|}{ Laboratory test data on admission } \\
\hline WBC & $5190 / \mathrm{ul}$ & $\mathrm{RF}$ & $269 \mathrm{IU} / \mathrm{ml}$ \\
\hline $\mathrm{Hb}$ & $10.0 \mathrm{~g} / \mathrm{dl}$ & MMP-3 & $121 \mathrm{ng} / \mathrm{ml}$ \\
\hline $\mathrm{Ht}$ & $30.5 \%$ & $\mathrm{C} 3$ & $141 \mathrm{mg} / \mathrm{dl}$ \\
\hline Plt & $12.0 \times 10^{4}$ & $\mathrm{CH} 50$ & $59.6 \mathrm{mg} / \mathrm{dl}$ \\
\hline CRP & $<0.2 \mathrm{mg} / \mathrm{dl}$ & $\mathrm{IgG}$ & $1315 \mathrm{mg} / \mathrm{dl}$ \\
\hline $\mathrm{TP} / \mathrm{Alb}$ & $5.0 / 2.3 \mathrm{~g} / \mathrm{dl}$ & $\operatorname{Ig} \mathrm{A}$ & $421 \mathrm{mg} / \mathrm{dl}$ \\
\hline $\mathrm{AST} / \mathrm{ALT}$ & $38 / 24 \mathrm{IU} / 1$ & $\operatorname{IgM}$ & $435 \mathrm{mg} / \mathrm{dl}$ \\
\hline ALP & $265 \mathrm{IU} / 1$ & \multicolumn{2}{|c|}{ ANA $80 \mathrm{X}$ (homogeneous, speckled pattern) } \\
\hline $\mathrm{Na}$ & $138 \mathrm{mEq} / 1$ & \multicolumn{2}{|c|}{ Anti-ds-DNAIgGAb $(-)$} \\
\hline K & $3.7 \mathrm{mEq} / 1$ & \multicolumn{2}{|c|}{ C-ANCA $(-)$} \\
\hline $\mathrm{Cl}$ & $105 \mathrm{mEq} / 1$ & \multicolumn{2}{|l|}{$\mathrm{P}-\mathrm{ANCA}(-)$} \\
\hline $\mathrm{Ca}$ & $7.3 \mathrm{mg} / \mathrm{dl}$ & \multicolumn{2}{|c|}{ Urinalysis : } \\
\hline (correct val & & \multicolumn{2}{|c|}{ Specific gravity : 1.019} \\
\hline BUN/Cre & $31.4 / 0.9 \mathrm{mg} / \mathrm{dl}$ & \multicolumn{2}{|c|}{$\mathrm{PH}: 5.5$} \\
\hline \multirow[t]{2}{*}{ UA } & $8.7 \mathrm{mg} / \mathrm{dl}$ & \multicolumn{2}{|c|}{ Occult blood : $3+\mathrm{RBC}: 6-10 / \mathrm{HPF}$} \\
\hline & & Urinary protein & $(5 \mathrm{~g} / \mathrm{g} \cdot \mathrm{Cr})$ \\
\hline
\end{tabular}




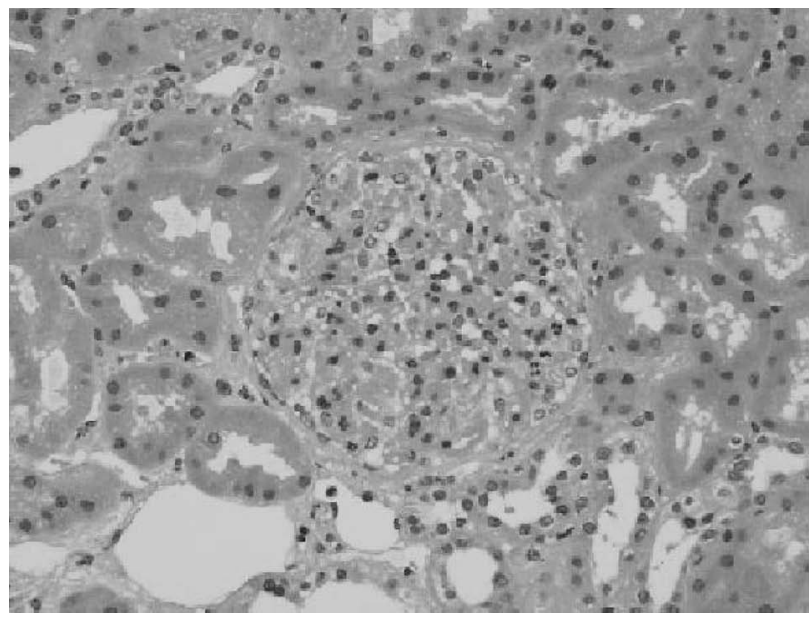

図 1 腎生検 $\mathrm{HE}$ 染色

糸球体は正常で，尿細管間質性線維化も認められなかった.

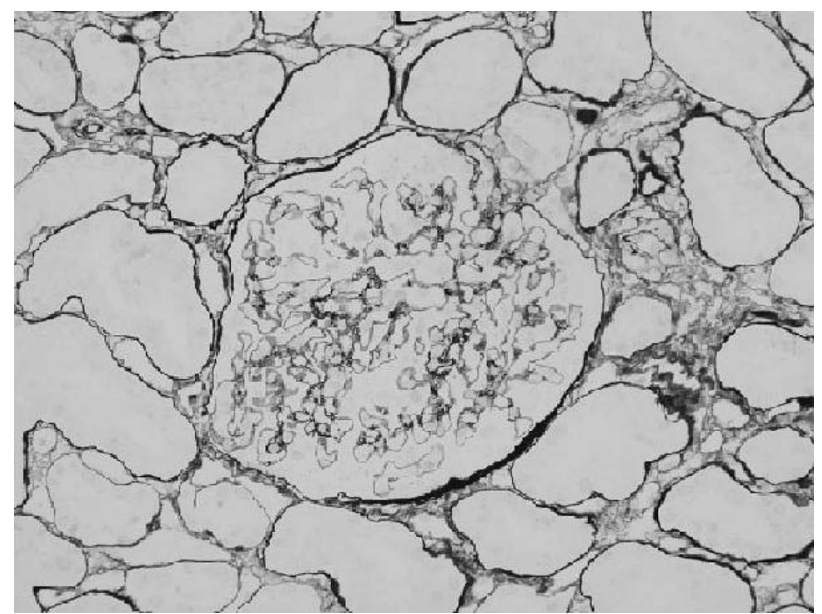

図 2 腎生検 Perodic acid silver methenamine (PASM) 染 色

基底膜の肥厚，二重化，スパイク形成は認めなかった。
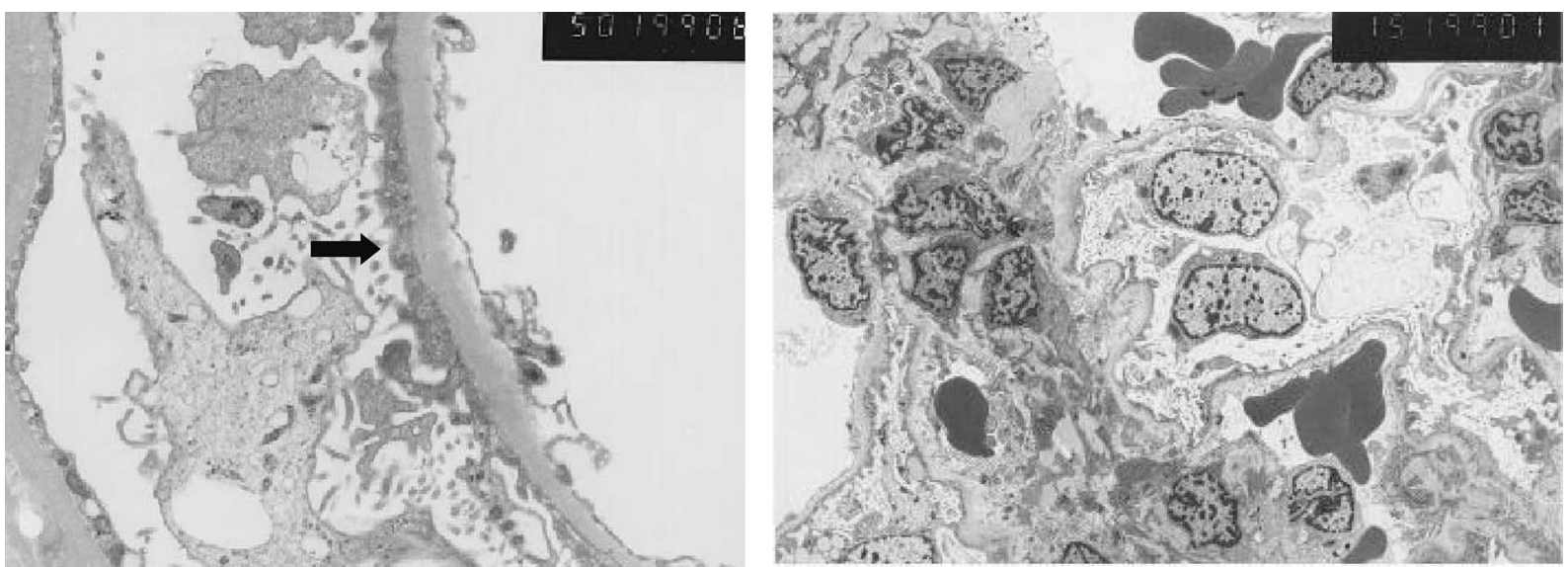

図 3 腎生検電顕

広範な足突起の閉鎖（effacement）（矢印）と上皮細胞にお打る微絨毛の存在を認めた。 なた糸球体基底膜には著変なく，デポ ジットも見られなかった.

あったこと，当科初診の 8 月 31 日に血清クレアチ ニンが $0.6 \mathrm{mg} / \mathrm{dl}$ であったのに, $1.0 \mathrm{mg} / \mathrm{dl}$ とやや 上昇傾向にあることを考慮して，12月 12 日よりプ レドニゾロン（PSL） $40 \mathrm{mg} /$ 日の内服を開始した.

その後も蛋白尿は順調に漸減傾向にあり 12 月 19 日より PSL $30 \mathrm{mg} /$ 日へ減量し，12月 27 日退院と なった。なお，現在も外来にて follow up 中であり，

PSL $5 \mathrm{mg}$ / 日内服にて 2006 年 9 月現在尿蛋白 40.1 $\mathrm{mg} / \mathrm{dl}(0.21 \mathrm{~g} / \mathrm{g} \cdot \mathrm{Cre})$, 血清アルブミン $3.8 \mathrm{~g} / \mathrm{dl}$ である.（表 3 に 2006 年 2 月 10 日迄の血清アルブ ミン，尿蛋白の推移を示した。）。 またRAの治療 は, サラゾスルファピリジン $1 \mathrm{~g} /$ 日の投与のみで, その後 RAの活動性を認めていない.

\section{考察}

RA に抢ける腎障害としては一般には DMARDs,

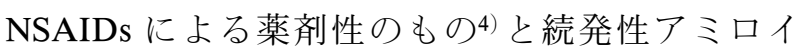

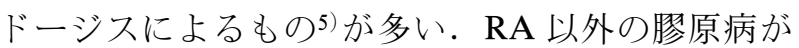
RA に合併しているいわゆるオーバーラップ症候群 では，SLE 合併例ではループス腎炎，強皮症合併 例では強皮症腎といった腎障害を認める場合6)もあ る.

本症例では発症してから半年しか経過していない RA であるため，RA そのものによる MCNS とは 考えにくい. 薬剤性の可能性としてはジクロフェナ クナトリウムと ETN しか投与していないためこの 両者を考えるが，前薬剤の投与前より蛋白尿が出現 していることから，同剤が本症例に打ける MCNS 
表 3 入院後の血清アルブミン，尿蛋白の推移

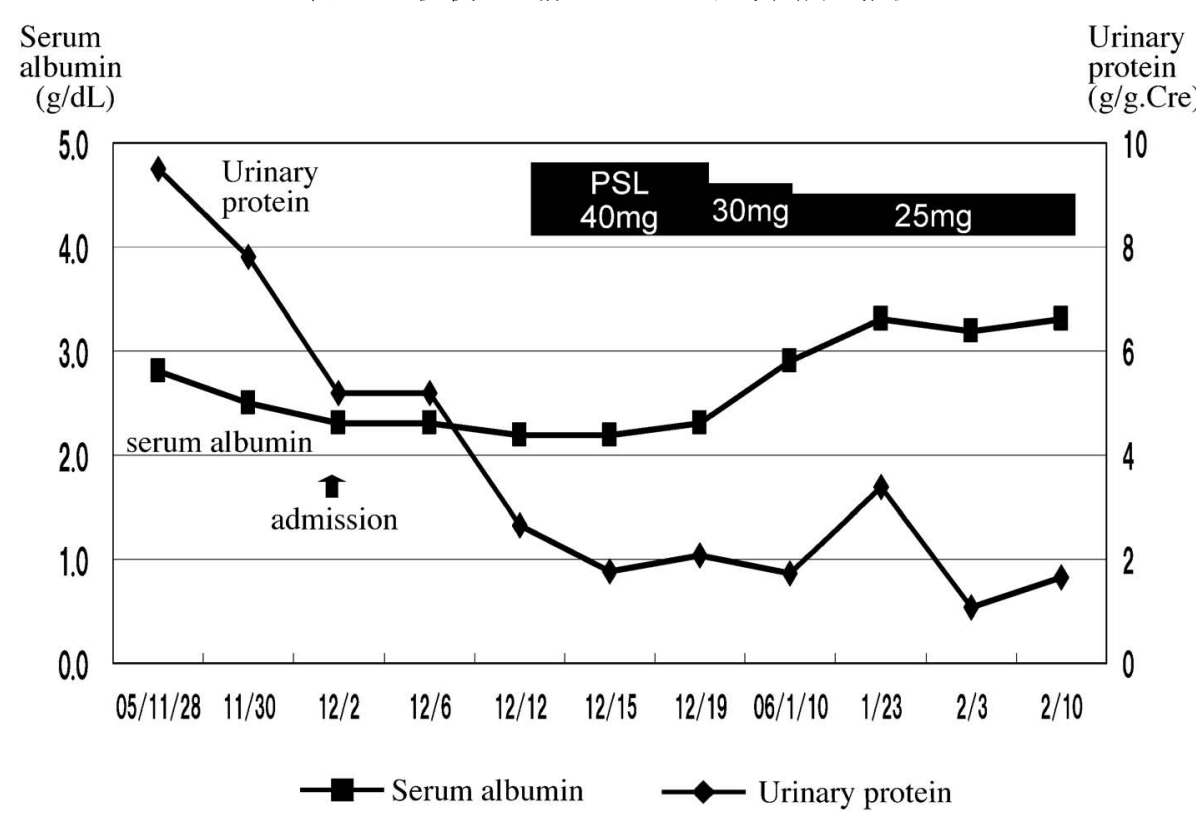

の発症原因であるとは考えられないＥTNの投与 開始後から蛋白尿が出現し，中止により軽減してい ったことを考慮すると，本症例に打り MCNSの 発症が ETN による有害事象である可能性が十分に 考えられる. その病態メカニズムに関しては, McCarthy らが，ラットの系球体で, $\mathrm{TNF} \alpha$ によっ てアルブミン透過性が増加し，抗 $\mathrm{TNF} \alpha$ 抗体を添 加することによりそうした作用が消失したといった 興味深い研究を発表しているが7), 生物学的製剤に よってNS が如何に発症するかといった病態解明に 関しての研究は検索した限りでは一つも見当たらな かった。

ETN の市販後全例調査の結果， 2005 年 12 月 31 日迄の 5519 例での副作用発現状況を見る限り，腎 障害は，NS を来した本症例の他に，腎出血 1 例， 血尿 2 例, 蛋白尿 4 例が認められるのみで, ETN は比較的腎障害の少ない薬剤である ${ }^{8)}$.このことは, 2006 年 3 月 31 日迄に ETN の投与が開始され，6 ヶ月の観察期間が終了した 7091 例の登録時合併症 としてNS が 14 例も報告されているにもかかわら ず9)，投与中にどの症例でも NS の増悪が認められ なかった事実からも肯定できる.

海外の文献では，Mor らが ETN 投与中に増殖性 ループス腎炎および白血球破砕血管炎を来たした 22 歳の若年性 RA の女性例を報告しており10)，こ れは ETNによる自己免疫機序の誘発といった意味 で，興味深い症例である。本例では ETN 投与前に 抗核抗体が陽性だったものの, いかなる疾患標識抗
体も認められず，未分化型結合組織病といった状態 であったが，Mor らの症例と同様な機序の可能性 も全く否定は出来ない。 また, Stokes らは2005 年 に TNF $\alpha$ 阻害薬治療後に糸球体腎炎を来した 5 症 例について報告している(11)。そのうち ETN 治療中 のものは 3 例で, 1 例目は, 7 歳時より重症 RA に 罹患している 30 歳の女性で, ETN 使用開始して 30 ヶ月後, NS を発症し, 抗 ds-DNA 抗体が陽性 化した。腎生検の結果は，ループス腎炎 (class IV, びまん性糸球体腎炎）であった. ETN 中止後 16 ケ 月で，PSL 投与により，軽快した。その 2 例目は， 45 歳時より重症 RA に罹患している，腎障害の既 往のない 55 歳, 男性例である. ETN 使用開始から 4 ヶ月後にNS を発症した. この症例は抗核抗体と P-ANCA が共に陽性で, 腎生検の組織学的診断は P-ANCA 関連巣状分節性壊死性および半月体形成 性糸球体腎炎であった。治療としては，シクロホス ファミドを開始し， ETN はその後も 4 ヶ月間継続 した. 肺血管炎を併発し，この時点で ETNを中止 した. 中止 5 力月後帯状疱疹と敗血症性関節炎など 重症感染症に罹患し, 結局死亡されたが, 剖検は行 われなかった。最後の症例は, 23 歳から RA に罹 患していた 53 歳，女性で，ETN 使用開始より 6 力 月後, NS が発症した。腎生検の組織学的診断は, 糸球体腎炎と免疫複合体性腎血管炎で，ETNを中 止して 3 ヶ月後, PSL, シクロスポリンの併用投与 により，尿蛋白は減少したという。

以上 Stokes らの 3 例と本例との比較から, 本例 
はこれら 3 例と異なり， RA 発症間もない症例であ

り ETN の直接作用でNS が発症したという可能性 が示唆される.

Stokes ら, Den Broeder ら, Chin らはこの他に adalimumab, infliximab 投与中の腎障害発症症例も 呈示しており11 13)，NS は ETN に特有なものでは なく，抗 TNF $\alpha$ 療法そのものによる有害事象であ ると考えられる。一般的には生物学的製剤では腎障 害を来たす頻度は低いと考えられているが，稀に本 症例のように MCNS を来たす場合もあり，生物学 的製剂を投与している症例では，臨床経過（腎機 能, 血清アルブミン, 抗核抗体, ANCA などの経 時的な検査も含めて）を観察することが必要である と思われる。

$$
\text { あとがき }
$$

ETN を投与中に MCNS を来した 1 症例を報告し た。本論文の要旨は第 34 回日本臨床免疫学会総会 (2006 年)にて発表した.

\section{文献}

1) Klareskog L., et al. : Therapeutic effect of the combination of etanercept and methotrexate compared with each treatment alone in patients with rheumatoid arthritis : double-blind randomised controlled trial. Lancet. $363: 675-681$, 2004.

2) van der Heijde D., et al.: Comparison of etanercept and methotrexate, alone and combined, in the treatment of rheumatoid arthritis : two-year clinical and radiographic results from the TEMPO study, a double-blind, randomized trial. Arthritis Rheum. 54 : 1063-1074, 2006.

3) Lipsky PE., et al. : Infliximab and methotrexate in the treatment of rheumatoid arthritis. AntiTumor Necrosis Factor Trial in Rheumatoid Arthritis with Concomitant Therapy Study Group. N Engl J Med. 343 : 1594-1602, 2000.
4) Nakano M, et al. : Analysis of renal pathology and drug history in 158 Japanese patients with rheumatoid arthritis, Clin. Nephrol. 50 : 154160, 1998.

5) Obana $\mathrm{M}$, et al. : Clinical studies on amyloidosis complicated with rheumatoid arthritis - with particular reference to nephropathy. Jpn $J$ Med. 29 : 274-282, 1990.

6) Takeuchi $T$, et al. : An autopsied case with a 21-year history of rheumatoid arthritis in which lupus nephritis and fatal cerebral bleeding depeloped. Clin Immunol. 15 : 744-751, 1983.

7) McCarthy ET, et al. : TNF- $\alpha$ increases albumin permeability of isolated rat glomeruli through the generation of superoxide. $J \mathrm{Am} S \mathrm{Soc}$ Nephrol. 9 : 433-438, 1998.

8) Information about the proper use. Vol. 4. Situation of manifestations of side effects according to a surveillance in all users. Enbrel ${ }^{\circledR}$ (etanercept) Japan prescribing information. Wyeth Phamaceuticals. Issue date June, 2006.

9) Information about the proper use. Vol. 6. Situation of manifestations of side effects according to a surveillance in all users. Enbrel ${ }^{\circledR}$ (etanercept) Japan prescribing information. Wyeth Phamaceuticals. Issue date June, 2007.

10) Mor A., et al. : Lupus nephritis and leukocytoclastic vasculitis during treatment with etanercept. J Rheumatol 32 : 740-743, 2005.

11) Stokes M B., et al. : Development of glomerulonephritis during anti-TNF- $\alpha$ therapy for rheumatoid arthritis. Nephrol Dial Transplant. 20 : 1400-1406, 2005.

12) Den Broeder A. A., et al. : Nephrotic syndrome as a complication of anti-TNF $\alpha$ in a patient with rheumatoid arthritis. Neth $J$ Med. 61: 137-141, 2003.

13) Chin G., et al. : Infliximab and nephrotic syndrome. Nephro Dial Transplant. 20 : 28242826, 2005. 